\title{
A New Approach to Exploring the Relationship between Weather Phenomenon and Truck Traffic Volume in the Cold Region Highway Network
}

\author{
Prasanta K. Sahu ${ }^{1}$, Leela Manas Bayireddy ${ }^{2}$ and Hyuk-Jae Roh $^{3, *}$ \\ 1 Department of Civil Engineering, Birla Institute of Technology and Science Pilani, Hyderabad Campus, \\ Telangana 500078, India; prasantsahu222@gmail.com \\ 2 Department of Civil Engineering, Birla Institute of Technology and Science Pilani, Pilani Campus, \\ Rajasthan 333031, India; leelamanas.bits@gmail.com \\ 3 City of Regina, Transportation \& Utilities, 1640 11th Avenue, Regina, SK S4P 3C8, Canada \\ * Correspondence: hyukjae.roh@gmail.com
}

Received: 15 September 2020; Accepted: 14 October 2020; Published: 15 October 2020

\begin{abstract}
Weather events are arbitrary, and this makes it difficult to incorporate weather parameters into transportation models. Recent research on traffic weather interaction analysis conducted at the University of Regina, Canada reported traffic variations with cold temperatures and snowfall. The research team at the University of Regina proposed a linear association between snowfall and temperature to analyze the traffic variation on provincial highways during winter months. The variations were studies with the inclusion of the expected daily volume factor as an independent variable in the model structure. However, the study did not analyze the nature of the association between daily truck traffic volume and snowfall. Based on these drawbacks of the past studies, in this research, the objective is to focus on the effects of snow and temperature on traffic volume changes with a methodological help of Maximal Information Coefficient (MIC), which stems from the maximal information-based nonparametric exploration (MINE) statistics. The results obtained from the analysis indicate that the relationship between snow and truck traffic is non-linear. However, the study could not establish any functional relationship between snowfall and daily truck volume. It is desired to further conduct an hourly analysis to explore a new relationship between snowfall and truck volume.
\end{abstract}

Keywords: MINE; MIC; correlation; snowfall; temperature; truck traffic

\section{Introduction}

Weather events are arbitrary and this makes it difficult to incorporate weather parameters into transportation models. The weather parameters include snowfall, temperature, precipitation, rainfall, smoke, wind speed, slit, hail, fog, lightning, etc. The weather has a significant impact on both roadway and its operation. The roadway impacts include obstruction in the lane change, significant damage to infrastructure, reduced visibility, etc. On the other hand, reduction in capacity and speed, increased delay, restrictions and closures, are the effects on traffic operation. Extreme weather events like lightning and extreme temperatures are responsible for the loss of communication/power and failure in traffic control. Further, choice of mode, driver behaviour and adaptability during different weather conditions influence the weather impact on mobility, safety and journey time.

Many researchers have worked on the analysis of the weather impacts on the variations of traffic volumes. In Scotland, Hassan and Barker [1] studied the changes in the average weekday traffic activity. In abnormal conditions of extreme temperatures, seasonally changed daylight hours and precipitation, they observed that variations in activity were less than $3 \%$ compared to normal conditions. While the 
snow was lying on the ground, there was an average decrease of $10 \%$ in traffic activity during weekdays. Angel and Sando [2] found that mean travel speeds have been reduced during rainfall events on Florida highways including the fact that increasing the intensity of rain caused greater reductions in speed. Furthermore, the results indicate that the hour of the day is a factor affecting the reduction of speed and traffic volumes by motorists during rainy conditions. This trend is more significant during peak hours. Singhal and Camille [3] reported that weather event affects transit ridership most during the weekday evening peak time (16:00-18:00) followed by midday peak duration (10:00-16:00), and least the morning peak period (06:00-10:00).

Traffic stream variations have been observed due to severe winter weather conditions in Canada and the northern regions of the USA [4-9]. Datla and Sharma [4] focused on the effects caused by winter climate conditions (snowfall and cold temperatures) on total traffic flow in the Alberta Highway network, Canada. They reported that significant changes in traffic variations were observed during the winter season, and the extent of change relies upon the locations of highway site, type of highway, the day of the week, the time of the day, and severity of weather conditions. The results indicated that the minimum decreases in traffic activity, up to $14 \%$, were observed on commuter type highways due mainly to colder temperatures. On the other hand, the highest reductions, up to $31 \%$, were experienced on recreational type highways. The effect of cold on traffic volume reduction raged from $6-10 \%$ during peak hours in commuter highways. In most cases, the reduction during off-peak hours ranging from $10-15 \%$ is higher than peak hours' reduction. On the contrary, in the case of recreational type highways, the peak hours' reduction ranging from $30-58 \%$ is higher than the off-peak hours that ranged from $18-30 \%$.

Most of the studies in this regard are limited to total traffic only. Research on truck traffic variations related to extreme winter conditions is valuable but scarce. An investigation on truck traffic pattern changes could be valuable to provide input to support purposes such as designing changes in highway and developing sustainable winter highway maintenance programs, geometric design of highway, highway life cycle analysis, and so forth. This study focuses on the possible truck traffic volume variations at six different highway sites in the Alberta highway network in Canada for the study period from 2005 to 2009. An investigation of the impact of snowy days on daily truck traffic volume factor is carried out using data collected from the different type of highway facilities. In Canada, Roh and Sharma [10] studied variations in highway truck traffic triggered by serious winter weather conditions. In their study, the traffic volume factor $\left(y_{\mathrm{i}}\right)$ was estimated with Equation (1) by considering snowfall, temperature, and expected daily volume factor (EDVF) as independent variables in the dummy variable regression model. It is revealed that the EDVF variable plays an important role to explain the variation of the estimated traffic volume because it contains systematic changes in historical data.

$$
y_{\mathrm{i}}=\beta_{1} E D V F_{\mathrm{i}}+\beta_{2} S N O W_{\mathrm{i}}+\sum_{j=1}^{6} \gamma_{j} C C_{i j}+\xi_{i}
$$

Roh and Sharma [11] conducted a similar study on passenger car and truck traffic using the same study site with this research. They proposed another linear model written in Equation (2) to quantify the effect of snow and temperature on traffic volume changes.

$$
y_{\mathrm{i}}=\beta_{1} E D V F_{\mathrm{i}}+\beta_{2} \text { Snow }_{\mathrm{i}}+\beta_{3} \text { Temp }_{\mathrm{i}}+\beta_{4} \text { Snow }_{\mathrm{i}} * \text { Temp }_{\mathrm{i}}+e_{\mathrm{i}}
$$

In the model, temperature and snowfall were taken as continuous independent variables. The model was specified to capture the interaction effect of snowfall and temperature by cooperating with a term composed of the product of two variables. However, still, the model contains the same independent variable, $E D V F$, and the term explains most of the variations in traffic volume changes. Therefore, the sensitivity of the effect of snowfall and temperature on traffic variations is not captured well and thus novel statistical approach is recommended to overcome the disadvantage of the models 
proposed in past studies. Based on these drawbacks of the past studies, in this research, the objective is to focus on the effects of snow and temperature on traffic volume changes with the methodological help of Maximal Information Coefficient (MIC), which stems from the maximal information-based nonparametric exploration (MINE) statistics created by Reshef and Reshef [12]. MIC measures the strength of the relationship between two variables $\mathrm{X}$ and $\mathrm{Y}$ and has been utilized as a non-parametric statistical method to recognize a novel relationship among huge information collected.

\section{Literature Review}

This section explains prior research in the field of climate effects on traffic. Studies related to the impact of weather events such as rain, snow and temperature on traffic volume have been released with some significant results. In the research conducted by Keay and Simmond [13], an examination regarding the impact of climate factor on traffic volume at Melbourne, Australia indicated rainfall is a factor that is correlated significantly with traffic volume changes. The amounts of decrease caused by rainfall in traffic volume were found to be $2.11 \%$ in spring and $1.35 \%$ in winter respectively. There were traffic volume reductions of $2-3 \%$ for the precipitation that ranged from $2 \mathrm{~mm}$ to $10 \mathrm{~mm}$; the highest reduction is $3.43 \%$ for the rainfall ranging from $2-5 \mathrm{~mm}$ in spring. Samba [14] investigated seven locations in Virginia and Minnesota and found that snow triggered traffic volume reduction up to $70 \%$ while the rain made $20 \%$ or less reduction. The amount of decrease in traffic volume fluctuated according to the time of day. During morning peak hours, little decreases were observed. Conversely, during early evening hours and afternoon peak hours, significant amounts of reductions ranging from $17-76 \%$ are observed. In the study of Sando [2] for the Florida roads, it was observed that the average amount of decrease in speed due to rain event ranged from 1.5 to $3.5 \mathrm{mph}$ for the control section of I-95, and it ranged from 1.8-2.5 mph for the control section of I-295. Hourly traffic volumes were also influenced by wet weather conditions. Average traffic demand is decreased by $2.5-10.7 \%$ under wet weather conditions along the I-95 and by $5.5-12.5 \%$ along the I-295.

Knapp and Smithson [5] identified that the average reductions in traffic ranged from $16-47 \%$ for various storm occasions. Hanbali and Kuemmel [15] have gathered information at 11 areas in the United States to investigate the impact of winter storm using the three months of data in 1991 and found that traffic volume is decreased on a weekday by $7-17 \%$ with light snow, but with substantial snow by $53 \%$, and on ends of the week by $19-31 \%$ and $56 \%$, respectively. Maze [16] found a solid relationship between perceivability, wind speed and decrease in traffic volume in his study on Interstate Highway 35 in Iowa during snowy days. He found a 20\% lessening in activity amid cold days with great perceivability and low wind speed. The decreases are around $80 \%$ when wind speed is high $(64.37 \mathrm{~km} / \mathrm{h})$, with perceivability under $0.40 \mathrm{~km}$.

In the study by Datla and Sharma [4], reductions in traffic volume have been indicated clearly with detailing on an hourly basis. In their model (see Equation (3)), the independent variable Expected Volume Factor (EVF) contribution was significantly higher as compared to snow and cold while estimating the daily traffic volume. Roh et al. $[10,11,17]$ also used similar models (see Equations (1) and (2)) and it was found that the EDVF can explain about $78 \%$ of classified traffic variation. These studies along with other similar studies as shown in Table 1 fail to explain the relationship between the traffic variation, snowfall and temperature. Roh's [17] work revealed that the linear association between snowfall and truck traffic volume is very low particularly in the case of a commuter type of road, although a linear model structure (see Equations (1) and (2)) was proposed in his study. Therefore, it would be worthwhile to detect a new relationship between weather variables and traffic volume variations with consideration of road type.

$$
V F_{W D Y C G}=B_{a} * E V F_{W D C G}+B_{s} * S_{W D Y C G}+\sum B_{R} * C_{R W D Y C G}
$$


where, $V F_{W D Y C G}$ is the daily volume factor of a particular day group " $\mathrm{D}$ " in the week "W" of a year " $Y$ " for the PTC site " $\mathrm{C}$ " that belongs to road type "G". EVF $F_{W D C G}$ is the average VF WDYCG calculated using all available years of data.

Table 1. Overview of prior research related to the effects of weather on highway traffic.

\begin{tabular}{|c|c|c|c|c|}
\hline Researcher & Location & Year & $\begin{array}{l}\text { Traffic Reduction Due } \\
\text { to Rainfall }\end{array}$ & $\begin{array}{l}\text { Traffic Reduction Due } \\
\text { to Snow }\end{array}$ \\
\hline Hassan and Barker [1] & Scotland & 1999 & $3 \%$ & $10 \%$ \\
\hline Angel and Sando [2] & Florida & 2014 & $\begin{array}{l}5.5-12.5 \% \text { per hour } \\
\text { along I-295 segment, } \\
2.5-10.7 \% \text { per hour } \\
\text { along I-95 segment }\end{array}$ & - \\
\hline Datla and Sharma [4] & Alberta & 2008 & - & $\begin{array}{l}\text { Commuter roads }-14 \% \text {, } \\
\text { Recreational roads- } 31 \%\end{array}$ \\
\hline Knapp and Smithson [5] & Iowa & 2000 & - & $\begin{array}{c}16 \% \text { to } 47 \% \text { for different } \\
\text { winter storms }\end{array}$ \\
\hline Roh et al. [10] & Alberta & 2015-2020 & & $\begin{array}{c}\text { Average snowfall } \\
(<15 \mathrm{~cm}) \text { and } \\
\text { Temperature greater } \\
\text { than } 25^{\circ} \mathrm{C} \text { do not affect } \\
\text { truck traffic }\end{array}$ \\
\hline Keay and Simmonds [13] & Melbourne & 2005 & $\begin{array}{l}1.35 \% \text {-Winter, } \\
2.11 \% \text {-Spring }\end{array}$ & - \\
\hline Samba and Park [14] & $\begin{array}{c}\text { Virginia, } \\
\text { Minnesota }\end{array}$ & 2011 & $20 \%$ & $70 \%$ \\
\hline Hanbali and Kuemmel [15] & $\begin{array}{l}\text { Illinois, Minnesota, } \\
\text { New York, } \\
\text { Wisconsin }\end{array}$ & 1993 & - & $\begin{array}{c}\text { Light snow: } \\
\text { 12\%-Weekday, } \\
\text { 25\%—Weekends, Heavy } \\
\text { Snow: } 53 \% \text {-Weekday, } \\
56 \% \text {-Weekends }\end{array}$ \\
\hline Maze [16] & Iowa & 2006 & - & $\begin{array}{l}\text { Low wind speed and } \\
\text { good visibility: } 20 \% \text {, } \\
\text { High wind speed and } \\
\text { poor visibility: } 80 \%\end{array}$ \\
\hline
\end{tabular}

Unlike previous studies, we attempted to explore the dependence of traffic volume on snowfall and cold temperature, by the use of Maximal Information Coefficient (MIC) and MINE Statistics. Reshef et al. [12] developed the MINE statistics and applied them to many data sets in diverse fields. In their study, they could identify some strong relationships that were unidentified by other correlation parameters like Pearson, Spearman, Kraskov Mutual Information, Principal curve-based estimator, etc. Later, MINE statistics were widely used in many other studies. Omar [18] identified many linear and nonlinear relationships in his cluster analysis of left ventricular and left atrial mechanical deformation parameters. Valenzo [19] utilized MIC in the estimation of Brain-heart linear and nonlinear coupling. Zhouzhou [20] used MIC to allow the computer to automatically identify some simple shapes of the final forms (spatial layouts) of the design (such as a circle or a U shape) and generate the correlation of each shape with the corresponding design performance.

\section{MIC, MINE Concept}

Reshef et al. [12] proposed a novel coefficient known as the Maximal Information Coefficient (MIC) to measure the relationship between two variables. MIC identifies both functional and non-functional relationships for a bivariate data set. MIC is a score ranging from 0 to 1 . If the value is close to 1 , a functional relationship can be established between the two variables and MIC value roughly equal to the coefficient of determination $\left(R^{2}\right)$ for that functional relationship. MIC satisfies two heuristic properties: generality and equitability. This means MIC is capable of suggesting all types of functional 
relationships and it gives a similar score to relations of different types at similar noise levels. Table 2 [12] represents some sample MIC values with varying noise levels for several functional relationships. Additionally to MIC, Reshef et al. [12,21] developed other statistics, which are collectively referred to as Maximal information-based Nonparametric Exploration (MINE) statistics. These statistics when used collectively help us in detecting and categorizing relationships. In their study [12], MIC and other MINE statistics were applied to data sets for global health, yeast gene expression profiles, 2008 major-league baseball season, and bacteria levels in the human gut microbiota and consequently identified known and novel relationships.

Table 2. Example of MIC values with varying noise levels for different functions.

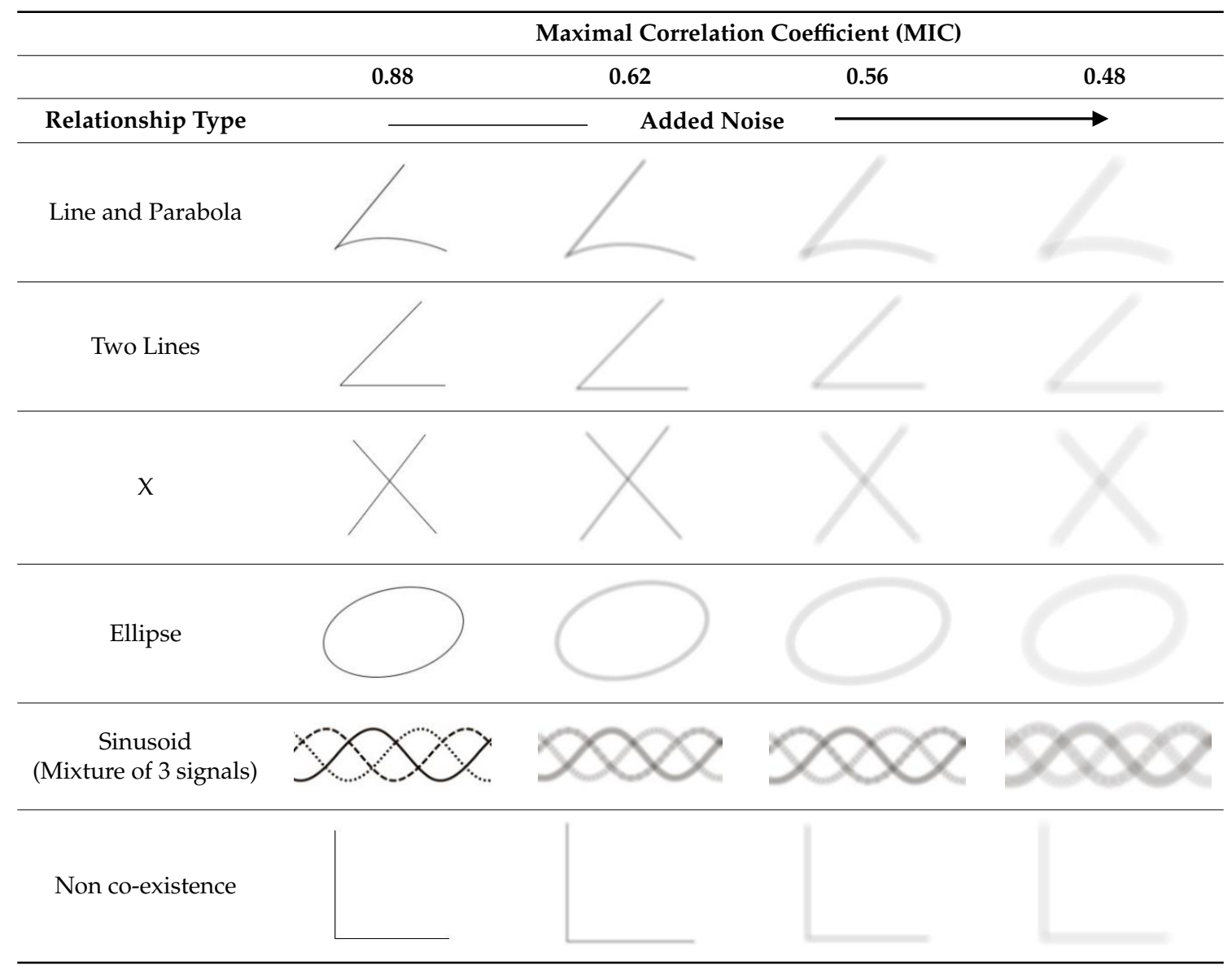

MIC explores the relationship between two variables. A grid is drawn on the bi-variate scatterplot to illustrate the relationship [4]. Additional statistics such as Maximum Asymmetric Score (MAS), Maximum Edge Value (MEV) and Maximum Cell Number (MCN) can be computed to determine the functional relationship between two variables. MAS represents the deviation from monotonicity. MEV suggests the closeness to a function, whereas MCN indicates the complexity of the closest function.

\section{Data}

Weigh-in-motion traffic data were obtained from six highway sites in the province of Alberta for this study. Six WIM sites are operating on Alberta Transportation's highway network. The traffic compositions for each site are shown in Table 3. Highway site names were chosen as per the neighboring city. Data obtained for a period of 5 years (2005 to 2009) were used for the analysis. Visual Basic (VB) program was used to extract the traffic data from raw WIM vehicle records. For each of the study sites, Truck Annual Average Daily Traffic (TAADT) values and the total number of vehicle records are presented in Table 3. Weather data were collected from Environment Canada weather information 
archives [22]. There are 598 weather stations operated by Environment Canada in the province of Alberta. The weather stations provide detailed weather parameters such as maximum, minimum, and mean temperature $\left({ }^{\circ} \mathrm{C}\right)$; total rain (millimetres); total snowfall (centimetres); total precipitation (millimetres); and snow on the ground (centimetres) on daily basis. Details of raw data format and measuring methods for each of these weather parameters are available from the Environment Canada website [22]. Based on the research done by Andrey and Olley [23] and Datla and Sharma [4] and using proximity analysis module in ArcGIS 10 [24], the nearest weather stations were considered in this study.

Table 3. Six WIM locations and vehicular records collected for each site in the Alberta Highway network and their traffic composition and traffic parameter.

\begin{tabular}{cccccc}
\hline Site Name & Lanes & TAADT & Passenger Cars (\%) & Trucks (\%) & No. of Vehicle Records \\
\hline $\begin{array}{c}\text { Red Deer on } \\
\text { Hwy 2-RD 3 }\end{array}$ & 4 & 4976 & 84 & 16 & $57,080,185$ \\
\hline $\begin{array}{c}\text { Leduc on } \\
\text { Hwy 2-LV 4 }\end{array}$ & 4 & 3964 & 83 & 17 & $44,386,644$ \\
\hline $\begin{array}{c}\text { Leduc on } \\
\text { Hwy 2A-LE 5 }\end{array}$ & 2 & 592 & 92 & 8 & $13,807,011$ \\
\hline $\begin{array}{c}\text { Fort MacLeod } \\
\text { on }\end{array}$ & 4 & 1075 & 85 & 15 & $12,835,403$ \\
Hwy 3-FM 6 & 4 & 2358 & 68 & 27 & $13,350,824$ \\
\hline $\begin{array}{c}\text { Edson Hwy on } \\
\text { Hwy 16-ED 7 }\end{array}$ & 4 & 73 & $12,673,164$ \\
\hline $\begin{array}{l}\text { Villeneuve on } \\
\text { Hwy 44-VI 8 }\end{array}$ & 2 & 2044 & Total Records & $154,133,231$ \\
\hline
\end{tabular}

\section{Methodology}

This study focuses on exploring the new relationship between truck traffic volume and weather parameters during weekdays with the help of the Maximum correlation coefficient (MIC). Daily volume factor (ratio of daily volume to average annual daily traffic) is used for analysis instead of absolute volume to take care of yearly variation in traffic volume. The variance in truck traffic volume factors (TRVF) for a specific day in a week was found to be lower when compared to variance TRVFs taken for all the days (weekday and weekend inclusive). Therefore, weekday volume is considered for analysis. The analysis is performed in two stages:

1. Classification of snowy days based on changes in weather conditions from the same weekday in the previous week.

2. MINE analysis on the obtained classified data.

Six different highways in Canada have been considered for analysis, ED7, FM6, LE5, LV4, RD3, and VI8, using the data from 2005-2009. Across all the highways, all snowy days (days on which snow was greater than $0 \mathrm{~cm}$ ) have been identified initially. We generated a new set of variables that relate snow $\left(\mathrm{S}_{\mathrm{i}}\right)$, temperature $\left(\mathrm{T}_{\mathrm{i}}\right)$ and truck volume factor $\left(\mathrm{TRVF}_{\mathrm{i}}\right)$ of the ith day of a week to the values $\left(\mathrm{S}_{\mathrm{i}-7}, \mathrm{~T}_{\mathrm{i}-7}, \mathrm{TRVF}_{\mathrm{i}-7}\right)$ in the previous week. The notations have been diagrammatically represented in Figure 1. Three new variables: Snow difference, Temperature difference, and Truck Volume Factor (TRVF) Difference are defined as follows: 


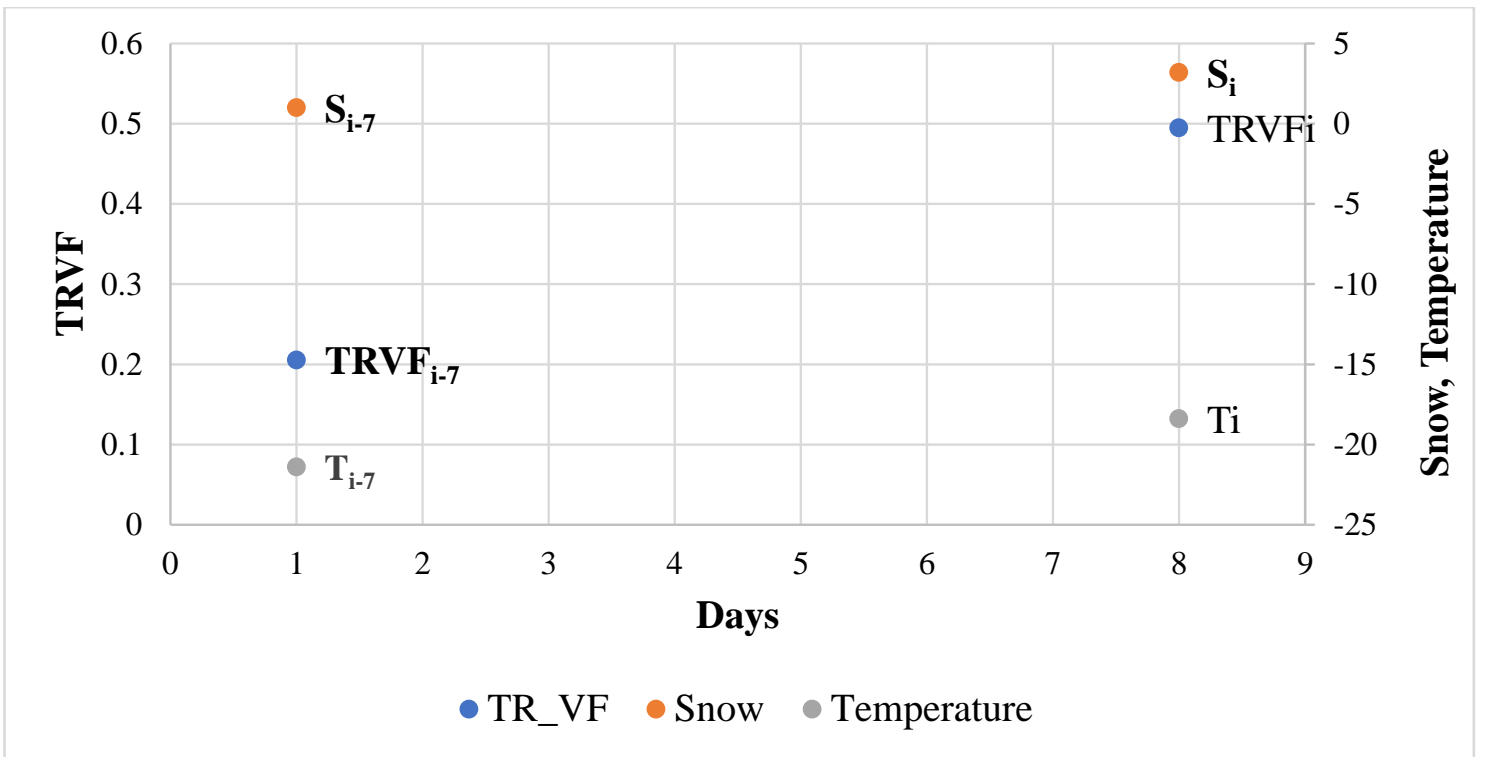

Figure 1. Diagrammatic representation of traffic variables (Snow, Temperature, and Traffic Volume

Factor) used in the study. Here, $\mathrm{i}=8$ and values in the graph are obtained from LV4 Highway data.

1. Snow Difference:

It is the difference in "snowfall on day of observation" and "snowfall on same weekday in the previous week".

$$
\Delta \mathrm{S}_{\mathrm{i}}=\mathrm{S}_{\mathrm{i}}-\mathrm{S}_{\mathrm{i}-7}
$$

where

$S_{i}=$ Snow on the ith day

$S_{i-7}=$ Snow on (i-7)th day (effectively same weekday in the previous week)

2. Temperature Difference:

It is the difference in "Temperature on day of observation" and "Temperature on same weekday in the previous week".

$$
\Delta \mathrm{T}_{\mathrm{i}}=\mathrm{T}_{\mathrm{i}}-\mathrm{T}_{\mathrm{i}-7}
$$

where

$\mathrm{T}_{\mathrm{i}}=$ Temperature on ith day

$\mathrm{T}_{\mathrm{i}-7}=$ Temperature on (i-7)th day (effectively same weekday in the previous week)

\section{TRVF Difference:}

It is the difference in "Truck traffic volume factor" on day of observation" and "Truck traffic volume factor" on the same weekday in the previous week".

$$
\Delta \mathrm{TRVF}_{\mathrm{i}}=\mathrm{TRVF}_{\mathrm{i}}-\mathrm{TRVF}_{\mathrm{i}-7}
$$

where

$\mathrm{TRVF}_{\mathrm{i}}=$ Truck traffic volume factor on ith day

TRVF $_{\mathrm{i}-7}=$ Truck traffic volume factor on (i-7)th day (effectively same weekday in the previous week)

For all the snowy days in each highway, the above-mentioned variable values were calculated, and based on their values, we categorized them into nine cases as defined below:

1. $\mathrm{C}_{1}$ Number of cases (days on which) when $\Delta \mathrm{S}_{\mathrm{i}}>0$ (snowfall increases), $\Delta \mathrm{T}_{\mathrm{i}}>0$ (temperature increases) and $\triangle T_{R V F}>0$ (traffic count increases) 
2. $\mathrm{C}_{2}$ Number of cases (days on which) when $\Delta \mathrm{S}_{\mathrm{i}}>0$ (snowfall increases), $\Delta \mathrm{T}_{\mathrm{i}}>0$ (temperature increases) and $\triangle \mathrm{TRVF}_{\mathrm{i}}<0$ (traffic count decreases)

3. $C_{3}$ Number of cases (days on which) when $\Delta S_{i}<0$ (snowfall decreases), $\Delta T_{i}>0$ (temperature increases) and $\Delta \mathrm{TRVF}_{\mathrm{i}}>0$ (traffic count increases)

4. $\mathrm{C}_{4}$ Number of cases (days on which) when $\Delta \mathrm{S}_{\mathrm{i}}<0$ (snowfall decreases), $\Delta \mathrm{T}_{\mathrm{i}}>0$ (temperature increases) and $\triangle \mathrm{TRVF}_{\mathrm{i}}<0$ (traffic count decreases)

5. $\mathrm{C}_{5}$ Number of cases (days on which) when $\Delta \mathrm{S}_{\mathrm{i}}<0$ (snowfall decreases), $\Delta \mathrm{T}_{\mathrm{i}}<0$ (temperature decreases) and $\Delta \mathrm{TRVF}_{\mathrm{i}}>0$ (traffic count increases)

6. $\mathrm{C}_{6}$ Number of cases (days on which) when $\Delta \mathrm{S}_{\mathrm{i}}<0$ (snowfall decreases), $\Delta \mathrm{T}_{\mathrm{i}}<0$ (temperature decreases) and $\triangle \mathrm{TRVF}_{\mathrm{i}}<0$ (traffic decrease)

7. $C_{7}$ Number of cases (days on which) when $\Delta S_{i}>0$ (snowfall increases), $\Delta T_{i}<0$ (temperature decreases) and $\triangle \mathrm{TRVF}_{\mathrm{i}}>0$ (traffic count increases)

8. $\mathrm{C}_{8}$ Number of cases (days on which) when $\Delta \mathrm{S}_{\mathrm{i}}>0$ (snowfall increases), $\Delta \mathrm{T}_{\mathrm{i}}<0$ (temperature decreases) and $\triangle \mathrm{TRVF}_{\mathrm{i}}<0$ (traffic count decreases)

9. $\mathrm{C}_{9}$ Number of cases for which, $\Delta \mathrm{S}_{\mathrm{i}}=0$ or $\Delta \mathrm{T}_{\mathrm{i}}=0$

Table 4. presents a summary of these case definitions. Among these nine cases, MINE analysis was performed on potential cases to derive meaningful interpretations. Figure 2 presents the different combinations of these eight case scenarios.

Table 4. Summary of definitions of eight cases.

\begin{tabular}{ccll}
\hline Case & $\Delta \mathbf{S}_{\mathbf{i}}$ & \multicolumn{1}{c}{$\boldsymbol{\Delta \mathbf { T } _ { \mathbf { i } }}$} & $\boldsymbol{\Delta} \mathbf{T R V F}_{\mathbf{i}}$ \\
\hline $\mathrm{C}_{1}$ & Increase & Increase & Increase \\
$\mathrm{C}_{2}$ & Increase & Increase & Decrease \\
$\mathrm{C}_{3}$ & Decrease & Increase & Increase \\
$\mathrm{C}_{4}$ & Decrease & Increase & Decrease \\
$\mathrm{C}_{5}$ & Decrease & Decrease & Increase \\
$\mathrm{C}_{6}$ & Decrease & Decrease & Decrease \\
$\mathrm{C}_{7}$ & Increase & Decrease & Increase \\
$\mathrm{C}_{8}$ & Increase & Decrease & Decrease \\
\hline
\end{tabular}




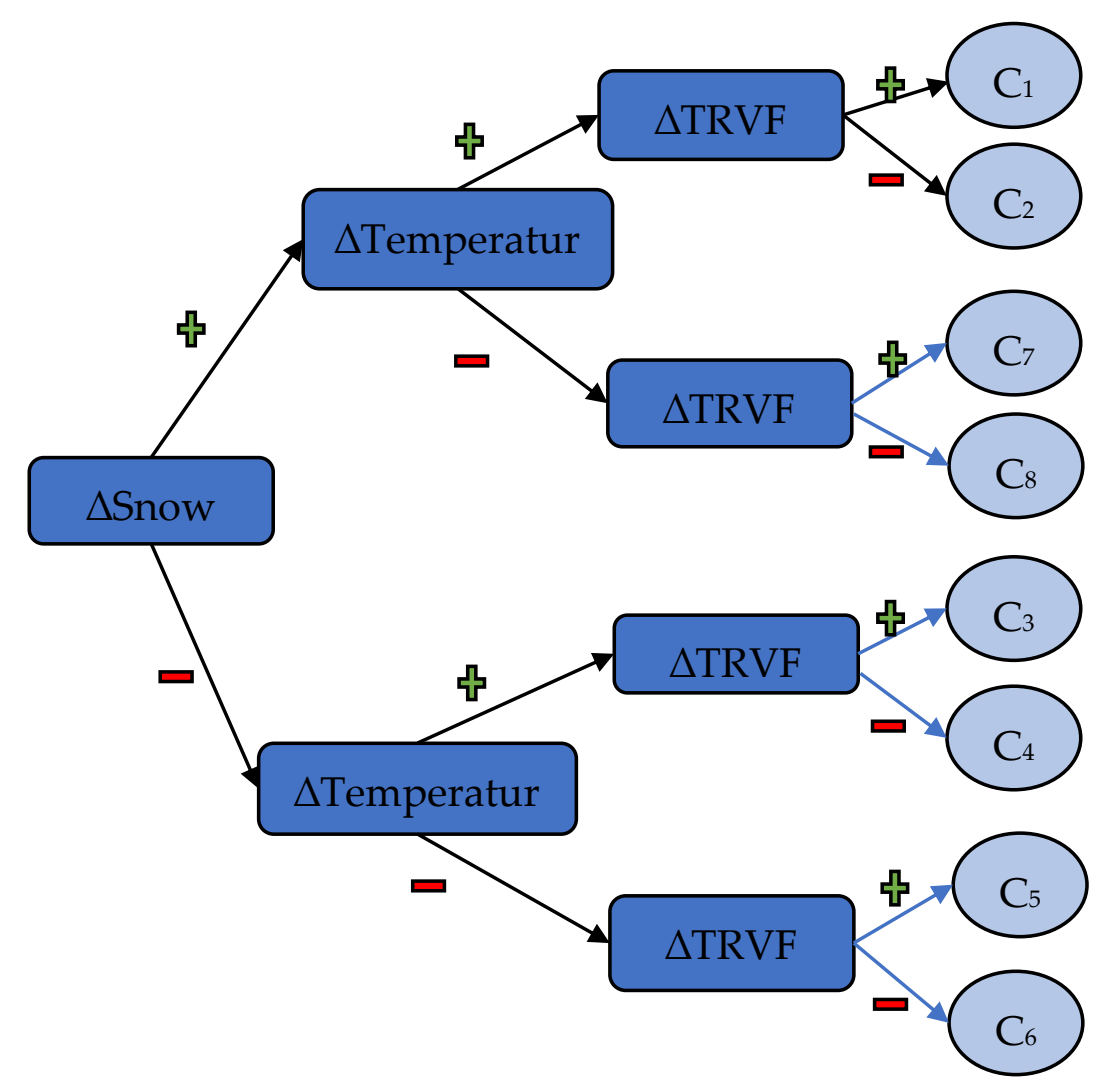

Figure 2. Schematic representation of eight cases: "+" indicates an increase in the parameter, "-" indicates a decrease in the parameter. C9 cases include those in which $\Delta S=0$ or $\Delta \mathrm{T}=0$.

\section{Results and Analysis}

The results indicate a higher number of cases favoring C8 in most of the highways (See Table 5). This hypothesizes that, during snowy days, when snowfall is higher and the temperature is lower, the truck volume experiences reduction. Past studies reports this is true in the case of total traffic, however, this effect has never been strong in the case of truck traffic. It is also observed that most of the cases belong to $\mathrm{C} 1, \mathrm{C} 2, \mathrm{C} 7$, and $\mathrm{C} 8$. These four categories have a common attribute that increases in snowfall. The higher number of cases for $\mathrm{C} 1$ than $\mathrm{C} 2$ implies that an increase in temperature caused an increase in traffic volume. Even though it is evident that snow has an impact on traffic reduction, it is important to determine the strength of the correlation between snow and truck traffic.

Table 5. Results of C1-C9 for six highway sites.

\begin{tabular}{cccccccccc}
\hline Highway & C1 & C2 & C3 & C4 & C5 & C6 & C7 & C8 & C9 \\
\hline ED7 & 9 & 8 & 1 & 0 & 1 & 1 & 16 & 27 & 3 \\
FM6 & 20 & 10 & 1 & 1 & 6 & 4 & 45 & 41 & 2 \\
LE5 & 38 & 31 & 5 & 5 & 9 & 7 & 41 & 53 & 6 \\
LV4 & 36 & 33 & 7 & 3 & 9 & 7 & 31 & 63 & 6 \\
RD3 & 27 & 27 & 4 & 2 & 5 & 4 & 37 & 68 & 3 \\
VI8 & 33 & 21 & 5 & 4 & 6 & 6 & 25 & 59 & 7 \\
\hline
\end{tabular}

To further explore the C 8 cases, MINE.r application in R software [17] was used over C8 cases for all the highways, with snow as an independent variable and truck volume factor (TRVF) as a dependent variable. Table 6 presents the results from MINE analysis on snow and truck volume factor. 
Table 6. MINE statistics for C8 cases (snow as independent variable and TRVF as dependent variable).

\begin{tabular}{ccccccc}
\hline $\begin{array}{c}\text { MIC } \\
\text { (Strength) }\end{array}$ & $\begin{array}{c}\text { MIC- }^{\mathbf{2}} \\
\text { (Nonlinearity) }\end{array}$ & $\begin{array}{c}\text { MAS } \\
\text { (Non-Monotonicity) }\end{array}$ & $\begin{array}{c}\text { MEV } \\
\text { (Functionality) }\end{array}$ & $\begin{array}{c}\text { MCN } \\
\text { (Complexity) }\end{array}$ & $\begin{array}{c}\text { Pearson } \\
\text { Correlation ( } \boldsymbol{\rho} \text { ) }\end{array}$ & Highway \\
\hline 0.325 & 0.318 & 0.148 & 0.325 & 2.585 & 0.084 & ED7 \\
0.300 & 0.287 & 0.091 & 0.300 & 3.000 & -0.115 & FM6 \\
0.318 & 0.247 & 0.080 & 0.279 & 3.322 & -0.267 & LE5 \\
0.412 & 0.147 & 0.072 & 0.367 & 3.585 & -0.515 & LV4 \\
0.346 & 0.295 & 0.165 & 0.305 & 3.585 & -0.226 & RD3 \\
0.266 & 0.206 & 0.042 & 0.238 & 3.585 & -0.245 & VI8 \\
\hline
\end{tabular}

Results in Table 6 suggest that there is no linear relationship between snowfall and truck traffic volume as opposed to the model presented in Equations (1) and (2). From the sample values of MINE statistics mentioned in Reshef's [8] study, it may be understood that the closest function that can be mapped to MIC of 0.412 would be that of a circle for the site LV4. Since such a function does not have practical significance (as it would predict two-volume factors for single snow value), it is desired to further conduct hourly analysis to explore a new relationship between snowfall and truck volume.

\section{Discussion and Conclusions}

The results obtained from the analysis indicate that the relationship between snow and truck traffic is non-linear. Despite proposing a model for predicting the traffic volume, Roh [6,25-29] also reported that there is no direct impact of snow on the truck traffic. However, the presence of a larger number of $\mathrm{C} 8$ cases, which are essentially the days on which truck traffic decreased due to increased snow and decreased temperature, indicates that there is some impact of snow and temperature on truck traffic volumes. This suggests that the correlation between snow and temperature, amongst C 8 cases, is better. This study serves the purpose of familiarizing MINE statistics to transportation research studies specifically related to truck traffic volume variation in the winter season. This research contributes to relaxing the limitation of analysis technique that has been limited to solely simple statistical and an intuitive traffic pattern analysis in the area of winter truck traffic pattern analysis. It is readily acknowledged we have a limitation in traffic data usage because daily truck traffic data is only available for this study due to the data collection practice of weather data that is usually aggregated daily. A deeper analysis of traffic volume hourly might reveal interesting correlations between snow, temperature and traffic volume through future research endeavors.

Author Contributions: The authors confirm contribution to the paper as follows: conceptualization: P.K.S., H.-J.R.; methodology: P.K.S., L.M.B.; software: P.K.S., L.M.B.; formal analysis: P.K.S., H.-J.R., L.M.B.; writing-original draft preparation: P.K.S., L.M.B.; writing-review and editing: P.K.S., H.-J.R.; visualization: L.M.B., P.K.S.; supervision: P.K.S., H.-J.R.; project administration: P.K.S., H.-J.R. All authors have read and agreed to the published version of the manuscript.

Funding: This research received no external funding.

Conflicts of Interest: The authors declare no conflict of interest.

\section{References}

1. Hassan, Y.A.; Barker, J.J. The impact of unseasonable or extreme weather on traffic activity within Lothian region, Scotland. J. Transp. Geogr. 1999, 7, 209-213. [CrossRef]

2. Angel, M.; Sando, M.; Chimba, D.; Kwigizile, V. Effects of rain on traffic operations on florida freeways. J. Transp. Res. Board 2014, 2440. [CrossRef]

3. Singhal, A.; Kamga, C. Impact of weather on urban transit ridership. Transp. Res. Part A Policy Pract. 2014, 69, 379-391. [CrossRef]

4. Datla, S.; Sharma, S. Impact of cold and snow on temporal and spatial variations of highway traffic volumes. J. Transp. Geogr. 2008, 16, 358-372. [CrossRef]

5. Knapp, K.K.; Smithson, L.D. Winter storm event volume impact analysis using multiple-source archived monitoring data. Transp. Res. Record 2000, 1700, 10-16. [CrossRef] 
6. Maze, T.H.; Crum, M.R.; Burchett, G. An Investigation of User Costs and Benefits of Winter Road Closures. 2005. Available online: http://lib.dr.iastate.edu/intrans_reports/21 (accessed on 20 October 2019).

7. Pierce, D.; Short, J. Road closures and freight diversion: Analysis with empirical data. Transp. Res. Record 2012, 2269, 51-57. [CrossRef]

8. Datla, S.; Sahu, P.; Roh, H.-J.; Sharma, S. A comprehensive analysis of the association of highway traffic with winter weather conditions. Procedia Soc. Behav. Sci. 2013, 104, 497-506. [CrossRef]

9. Bardal, K.G. Impacts of adverse weather on arctic road transport. J. Transp. Geogr. 2017, 59, 49-58. [CrossRef]

10. Roh, H.J.; Sharma, S.; Sahu, P.; Datla, S. Analysis and modeling of highway truck traffic volume variations during severe winter weather conditions in Canada. J. Mod. Transp. 2015, 23, 228-239. [CrossRef]

11. Roh, H.J.; Sahu, P.; Sharma, S.; Datla, S.; Mehran, B. Statistical investigations of snowfall and temperature interaction with passenger car and truck traffic on primary highways in Canada. J. Cold Reg. Eng. 2016, 30. [CrossRef]

12. Reshef, D.N.; Reshef, Y.A.; Finucane, H.K.; Grossman, S.R.; McVean, G.; Turnbaugh, P.J.; Lander, E.S.; Mitzenmacher, M.; Sabeti, P.C. Detecting novel associations in large data sets. Science 2011, 334, 1518-1524. [CrossRef] [PubMed]

13. Keay, K.; Simmonds, I. The association of rainfall and other weather variables with road traffic volume in Melbourne, Australia. Accid. Anal. Prev. 2005, 37, 109-124. [CrossRef] [PubMed]

14. Samba, D.; Park, B. Incorporating inclement weather impacts on traffic estimation and prediction. In Proceedings of the 18th ITS World Congress on Intelligent Transportation Systems, Orlando, FL, USA, 16-20 October 2011.

15. Hanbali, R.M.; Kuemmel, D.A. Traffic Volume Reduction Due to Winter Storm Conditions; Transportation Research Record, No. 1387; Transportation Research Board of the National Academies: Washington, DC, USA, 1993; pp. 159-164.

16. Maze, T.H.; Agarwal, M.; Burchett, G.D. Whether Weather Matters to Traffic Demand, Traffic Safety, and Traffic Operations and Flow; Transportation Research Record, No. 1948; Transportation Research Board of the National Academies: Washington, DC, USA, 2006; pp. 170-176. [CrossRef]

17. Roh, H.J. Impacts of Snowfall, Low Temperatures, and Their Interaction on Passenger Car and Truck Traffic. Ph.D. Thesis, Department of Environmental Systems, University of Regina, Regina, SK, Canada, 2015.

18. Omar, A.M.S.; Narula, S.; Rahman, M.A.A.; Pedrizzetti, G.; Raslan, H.; Rifaie, O.; Narula, J.; Sengupta, P.P. Precision phenotyping in heart failure and pattern clustering of ultrasound data for the assessment of diastolic dysfunction. JACC Cardiovasc. Imaging 2017, 2157. [CrossRef]

19. Valenza, G.; Greco, A.; Gentili, C.; Lanata, A.; Sebastiani, L.; Menicucci, D.; Gemignani, A.; Scilingo, E.P. Combining electroencephalographic activity and instantaneous heart rate for assessing brain-heart dynamics during visual emotional elicitation in healthy subjects. Philos. Trans. R. Soc. Lond. A 2016, 374. [CrossRef]

20. Zhouzhou, S.; Wei, Y. Creating and improving a closed loop: Design optimization and knowledge discovery in architecture. Int. J. Archit. Comput. 2015, 13, 123-142. [CrossRef]

21. Available online: http://www.exploredata.net/Downloads/MINE-Application (accessed on 6 January 2017).

22. Environment Canada (EC) (2010) Weather Office, Gatineau, Quebec, Canada. Available online: www.climate. weatheroffice.gc.ca/climateData/canada_e.html (accessed on 20 October 2016).

23. Andrey, J.; Olley, R. Relationships between weather and road safety, past and future directions. Climatol. Bull. 1990, 24, 123-137.

24. Environmental System Research Institute Inc. (ESRI) (2010) ArcGIS 10 Help Library: Geographic Information System (GIS); ArcGIS 10: Redlands, CA, USA, 2010.

25. Roh, H.J. Developing cold region winter-weather traffic models and testing their temporal transferability and model specification. J. Cold Reg. Eng. 2019, 33. [CrossRef]

26. Roh, H.J. Modelling chronic winter hazards as a function of precipitation and Temperature. Nat. Hazards 2020, 104. [CrossRef]

27. Roh, H.J. Spatial transferability testing of dummy variable winter-weather model using traffic data collected from five geographically dispersed weigh-in-motion sites in Alberta highway networks. J. Transp. Eng. A Syst. 2020, 146. [CrossRef]

28. Roh, H.J. Development of winter climatic hazard models on traffic volume and assessment of their performance with four types of model structures. Nat. Hazards Rev. 2020, 21. [CrossRef] 
29. Roh, H.J. Assessing the effect of snowfall and cold temperature on a commuter highway traffic volume using several layers of statistical methods. Transp. Eng. 2020, 2. [CrossRef]

Publisher's Note: MDPI stays neutral with regard to jurisdictional claims in published maps and institutional affiliations.

(C) 2020 by the authors. Licensee MDPI, Basel, Switzerland. This article is an open access article distributed under the terms and conditions of the Creative Commons Attribution (CC BY) license (http://creativecommons.org/licenses/by/4.0/). 